\title{
Sovereign Wealth Fund's (Swf) Increasing Role as Bank Capital Provider to Indian Banks
}

\author{
N. Krishna Kumar
}

\begin{abstract}
In a globalised uni-polar world, the influence of Capital Providers is shifting from Private Actors to that of Public Actors. The role played by government owned investment funds or Sovereign Wealth Funds (SWF) is becoming pronounced and it has crossed \$ 8.4 trillion recently in 2021.

The paper examines and explains the issue of SWFs with specific reference to its role as a provider of Banking Capital to distressed banks in a stressful situation. The recent case of DBS India's take over of Lakshmi Vilas Bank is also a case in point. $A$ review of the context and an evaluation of the strategic risks involved with regard to governance, economy, regulation and geo-politics are also flagged with clear evidenced perspectives. The issues raised in the paper has high topical relevance to the world of Money and Finance in general and Banking Capital in particular.
\end{abstract}

Key Words: Sovereign Wealth Funds, Scarcity of Banking Capital, State-Adaptive Strategy, Sovereign Investment Vehicle, SWF as Provider of Banking Capital.

\section{INTRODUCTION}

Finance capitalism is driving the World. It is but natural to expect foreign money to find its way, to pump ailing weak banks, especially in the stressful conditions many Banks in the developing world are placed. It is a common knowledge that in the past one decade or so, beleaguered banks due to decelerating economy, raising NPA levels and many other structural impediments were finding it difficult to garner capital. The weaker banks faced the brunt of it. In India, the old generation banks, with myriad governance issues and regulatory compulsions of the nature of Basel III guidelines and the like were finding it very difficult to raise capital, repeatedly. More specifically, some banks were classified into weak banks and put under Prompt-Corrective Action (PCA) Framework of the Reserve Bank of India. In short, the Prompt Corrective Action or PCA is a framework under which banks with weak metrics on Capital Ratios, Asset Quality and Profitability concerns are put under watch by the RBI. Such classification deems bank as risky and starts corrective actions which majorly includes Capital infusion and probing Governance issues. Accordingly, some Private Banks like Yes Bank, Lakshmi Vilas Bank, Dhanlaxmi Bank, CSB etc. apart from the Nationalised Banks in India like UCO Bank, Indian Overseas Bank have been categorized under PCA framework in the last two-three years.

Manuscript received on 01 April 2021 | Revised Manuscript received on 07 April 2021 | Manuscript Accepted on 15 April 2021 | Manuscript published on 30 April 2021.

* Correspondence Author

Narayanan Krishna Kumar, Ph. D Dean, State Bank Institute of Leadership (SBIL), Kolkata, India. dean.sbil@sbi.co.in

(c) The Authors. Published by Lattice Science Publication (LSP). This is an open access article under the CC-BY-NC-ND license (http://creativecommons.org/licenses/by-nc-nd/4.0/)

\section{SCARCITY OF FRESH CAPITAL TO FUND WEAK BANKS}

Banks when trying to pull out from the quagmire of such distress, raising fresh Capital from the investors is always a conundrum that plays out. 'Suitors' are looked around for the 'Bride', but generally it ends up as a long process and 'Suitors-with-deep-pockets' are always a preferred lot in the game.

They might come from far and wide after hearing the news. In the globalised world of Finance Capital, Sovereign wealth funds (SWF) are emerging as one such major 'Suitors' in supplying banking capital, or that is what the recent merger of 'Lakshmi Vilas Bank' points out, going by the fact the Development Bank of Singapore (DBS) which has taken over the LVB is a Bank where in Temasek Holdings one of the SWF of Singapore Government has the majority stake. Now, herein we need to understand the SWF with more clarity.

\section{HOW IS SWF COMING UP IN THE SCENE?}

SWFs are investment funds owned by sovereign governments and is funded by foreign exchange and reserve assets. They are generally funded by reserves held by countries running current account and budgetary surpluses. It is categorized by their longer-term investment horizons as well as their different objectives. Since an SWF Balance sheet doesn't carry much of liabilities it helps them with long-term goals/ outlook when making an allocation. In fact, SWFs can be the "stickiest" of all institutional investors, as they seek returns over long periods and do not divest in times of crisis.

But when we come to specifics (incl. investments in financial sector or in Venture Funds) probably some are not aware of the role played by Government owned investment funds or Sovereign Wealth Funds. SWFs are supposed to be wielding financial muscle in excess of \$ 8.4 trillion now. (Source : IE Sovereign Wealth Fund Research, 2019) . In terms of asset size, it has already outgrown Hedge funds, Private Equity Funds etc., though its quantum is small, when compared to Assets held by Pension Funds, Mutual Funds or Insurers. From the above information, discussions and references, it shall be clear why a better understanding of SWF is required, especially when the composition of FDI is undergoing changes from private actors to public actors. This article examines and provides insights into what this sovereign investment vehicle has brought about, into governance, regulatory and strategic aspects of international business. More specifically, its investment in Banking capital and what it signifies.

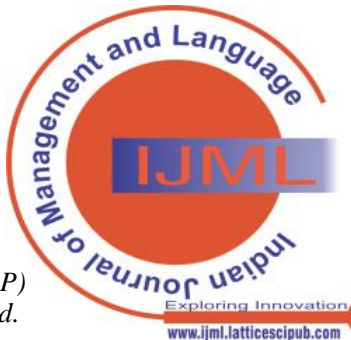




\section{MERGER OF LVB WITH DBS AND THE SOVEREIGN CONNECTION}

As we all know, the beleaguered capital starved Lakshmi Vilas Bank (LVB) was merged with DBS Bank in India in a sudden move. It opened an initial shock and awe followed by many legal disputes to this day. The poor due-diligence that has gone into finding the suiter in a jiffy was heavily criticised. Majorly, the following reasons were pointed out and are still getting debated in the common circles

(i) No proper calling of suiters and evaluations/ vetting done to take care the interests of all stake-holders;

(ii) Leaving in lurch of all the existing equity holders;

(iii) Leaving in lurch the AT1 Bond holders when the merger was announced (including LIC's contribution);

(iv) A foreign Bank getting a complete stake in an Indian Private Bank with 563 branches for nothing.

But the biggest question that should harbour the attention should have been on the Control the Sovereign Wealth Fund of Singapore Government ie., Temasek Holding has on DBS Bank in their Country. The following aspects could have merited attention.

(i) It is puzzling considering the fact that Foreign Banks Operations in any Country is by way of reciprocity of 'market access' and foreign banks who are operating in India for even more than 100 years like CITI Bank, Standard Chartered, HSBC etc., could grow only to a size of 15 or 20 branches in the Country.

(ii) Opening / allowing of foreign banks to function in the country has always been the subject matter of Comprehensive Economic Co-operation Agreements between Countries. When it comes to India and Singapore case, despite the fact that we boast of a nearly Century old banking co-operation with Singapore, till date, only eight Indian Commercial Banks operate in Singapore. All with just a lone branch except UCO Bank which is the oldest and has two branches. The regulator Monetary Authority of Singapore hasn't given any automatic entry into Singapore at any point in time. In such a situation why this largesse.

(iii) It could be another matter that more than 30 overseas branches of Indian commercial Banks were closed down in the last two years due to varied reasons (including viability related).

(iv) The moot question again is why to a Bank with highest holding of a sovereign focussed fund ?. Isn't it indirectly allowing the foreign government itself

Scholars and Researchers who have studied SWF have conflicting views about its increasing role in the world economy. Some argue that SWF are a result of balance of payment surpluses and are used for economic smoothening purposes (Mattoo \& Subramanian, 2008). There is an alternative view published in the same year stating that this theory is unfounded (Madden, 2008). An extreme view set forth in the thesis by Norris (in 2010) is that SWFs deliberately tries to pursue and generate their strategic goals by manipulating the activities of commercial actors and are engaging in economic statecraft. Another view is, SWF can access?

be seen as a state-adaptive strategy under contemporary conditions of globalisation (Monk, 2011). It is an evolving theme and little attention is focused on SWF's use by states as a tool in promoting national development.

\section{GROWTH AND INCREASING CLOUT OF SWFS}

It is an established fact by research, that cross-border financial flows as investments in value creating activities in diverse economies, looks for productivity of financial capital in a globalized world which has seen a shift towards a more integrated and inter-dependent world economy. The shift in financial power from private to public actors, has led to examination of SWF operations and its implications for the world economy.

Sign of the growing clout that state-backed investment vehicles are wielding in the financial sector has been evident for some time now. The flow of cash from state-backed agencies, especially those based in Asia or the Middle East, is prompting concern among politicians in Europe and the US, who worry it may give foreign governments influence over the financial sector.

\section{PROBLEM AREAS / ISSUES IN SWF FUNDING}

The following could be termed as major issues with regard to the growth and emergence of SWF in the world :

$>$ Researchers who studied the Financial Crisis and Economic Downturns globally post 2007, be it Mortgage Crisis emanating from the Sub-prime mortgages involving Collateralised Debt Obligations(CDOs)/ Credit Default Swaps (CDS) and derivatives or the bail-out of countries on the brink of sovereign default like Greece or Dubai, have pointed out, the increasing role played by SWF in the bail-out packages. It can be argued, that the SWFs, irrespective of origin, have turned every crisis into an opportunity in their growth path.

$>$ In addition to the national security concerns, many economists and policy makers are of the opinion that by investing in failed institutions by injecting billions of dollars the SWFs are engaged in an act of disrupting the natural part of business cycles which would have removed ineffective management and poorly performing companies / corporations from the market place.

$>$ Studies on foreign investment literature suggest many Non-financial motives to investing by SWF. The relation between SWF investment and target firm performance has been a subject matter of debate and many researchers who worked on this subject suggest that the SWFs prefer large poorly performing firms facing financial difficulties. This is contrarian to professional investment logic and philosophy. Another set of studies seem to prove that the SWFs investments have a positive effect on the stock prices of target firms around the date of announcement of investment but no effect on the firms performance / governance in the long run. 
However, many market operators irrespective of nationalities support SWFs as they provide the much needed liquidity to the capital market.

$>$ A new business model of SWF that is evolving and emerging is to form unusual alliances. For instance, the Abu Dhabi Investment Authority (ADIA) has formed a joint venture with Kuwait Investment Authority (KIA) and the Korean National Pension Service. Same way, the Chinese Investment Corporation (CIC) entered into a 50-50 joint venture with an SWF in Singapore. Many such known and un-known partnerships or strategic tie-ups have come about in the last five years or so. Such partnering apart from giving edge in financial leverage and negotiation is also meant for political cover is the argument by experts in the subject.

$>$ Many Legal issues and Tax issues have also cropped up with the growth of SWF in the world of foreign investment. Though the taxation of foreign investments is a favourable one with exemptions from capital appreciation or dividend income in many countries, it has come into conflict with domestic / foreign private equity investors. There is an issue of 'level playing ground' often touted by the domestic investors when it comes to tax exemptions.

$>$ The next issue relates to foreign investment climate. In India, to some extent in our enthusiasm to attract foreign capital, we have also liberalised the investment regime. In May 2016, the RBI allowed foreign banks to acquire 10 per cent in Indian Private Banks. The circular further allows foreign banks to take higher stake in private banks in the case of re-structuring of a weak bank or in the interest of consolidation in the banking sector though subject to certain conditions. The RBI Circulars subsequently have also favoured the Wholly-owned Subsidiaries (WOS) of Foreign Banks to increase its presence. The DBS India is a WOS in India and Temasek Holding, promptly used the leeway to scale up. Whether, culturally and economically does it make sense to take such a risk when banking itself is going to be less and less brick-and-mortar is another matter. In the current takeover of the weak Lakshmi Vilas bank in India by the SWF supported DBS India in Nov 2020, the motive, transparency and the real objective is unclear.

$>$ There is also an issue of systemic risk, from SWF singly or acting in tandem, through its investments in Global banks, as is noticed in sub-prime days when SWFs raised their stakes in big global banks like Citigroup, UBS, Morgan Stanley, Barclays etc.

\section{CONCLUSION}

SWFs are increasingly metamorphosing from passive investors in government securities to active investors in riskier investments and equity markets. The component of SWF in Inward FDI is going up in the world which clearly underscores the risks emanating from sovereign actors in the conduct of international business. Arguably, this brings with it a bouquet of issues with regard to Banking Capital, governance, management and regulatory aspects in world of investing and banking business. The goal of this article was to provide insights for a better understanding of the SWF, in such a fast changing landscape of Banking \& Finance.

\section{REFERENCES}

1. Aizenman, J. and R. Glick, "Sovereign Wealth Funds: Stumbling Blocks or Stepping Stones to Financial Globalization?," FRBSF Economic Letter, No. 38, San Francisco, November 2007.

2. Almunia, Joaquin, "The EU Response to the Rise of Sovereign Wealth Funds" speech delivered at the Crans Montana Forum, Brussels, April 2, 2008.

3. Avendano, R. \& Sanitiso, J. (2010). Are sovereign wealth fund investments politically biased? Company mutual and sovereign fund. Retrieved from http://www.voxEU.org. [CrossRef]

4. Backer, L.C. (2010a). Sovereign investing in times of crisis: Global regulation of sovereign wealth funds, state-owned enterprises, and the Chinese experience. Transnational Law and Contemporary Problems, 19(1). Retrieved from http://www/law.uiowa.edu/journals/tlcp

5. Backer, L. C. (2010b). Sovereign wealth funds as regulatory chameleons: the Norwegian sovereign wealth funds and public global governance through private global investment. Georgetown Journal of International Law, 41(2), 425-500.

6. Chang, S. \& Rhee, J. H. (2011). Rapid FDI expansion and firm performance. Journal of International Business Studies, 42(8), 979994. [CrossRef]

7. Ford, N. (2011). Challenging times for Gulf SWFs. Middle East, 422, 35-37.

8. Hader, L. T. (2008). Balance of power is continuing to shift from the U.S. The Cato Institute. Retrieved from http://www.cato.orgID=9417.

9. Kotter, J. \& Lel, U. (2011). Friends or foe? Target selection decisions of SWFs and their consequences. Journal of Financial Economics, 101(2), 360-381. [CrossRef]

10. John R Patton (2012), Sovereign Wealth Funds in a Globalized World, International Business - Research, Teaching and Practice, Journal of AIB-SE, 20126 (1)

11. Madden, C. L. (2008). Sovereign wealth funds under scrutiny. Policy Innovations. Carnegie Council,May21.Retrieved from http://www.policyinnovations.org/ideas/ briefings.

12. Mattoo, A. \& Subramanian, A. (2008). Currency undervaluation and sovereign wealth funds: A new role for the WTO. Working Paper 08-2, January. Peterson Institute for International Economics, 1-31. Retrieved from http://www.petersoninstitute.org. [CrossRef]

13. Mauck, N. (2011). Two essays on sovereign wealth funds. Ph.D. Dissertation, Florida State University, College of Business, spring, 1-80.

14. Mitchell, D. J. (2007). Supermodels and monetary policy. The Cato Institute. Retrieved from http://www.cato-at-libery.org/supermodelsand-monetarypolicy.

15. Monk, A. H. B. (2011). Sovereignty in the era of global capitalism: the rise of sovereign wealth funds and the power of finance. Environment \& Planning A, 43(8), 1813-1832. [CrossRef]

16. Norris, W. J. (2010). Economic statecraft with Chinese characteristics: the use of commercial actors in China's grand strategy. Ph.D. Thesis, MIT. Retrieved from http://proquest.umi.com.

17. Pistor, K. (2009). Sovereign wealth funds, banks, and governments in the global crisis: Towards a new governance of global finance? European Business Organization Law Review, 10, 333-352. [CrossRef]

18. Schwartz, A. J. (2009). Origins of the financial market crisis of 2008. Cato Journal, 29(1),19-23. [CrossRef]

19. UNCTAD (2010). World Investment Report 2010: Investing in a Low-Carbon Economy. New York: United Nations.

\section{AUTHORS PROFILE}

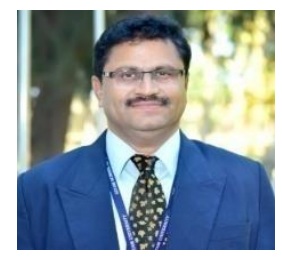

Prof. (Dr). Narayanan Krishna Kumar, is a bank executive turned academic turned leadership Trainer. He is currently 'Dean' and Head of Academics at State Bank Institute of Leadership (SBIL). SBIL is the Apex Training Institute of the State Bank of India and is an integral part of the Bank. (World's largest Bank by Branches). He has nearly 3 decades of experience spanning Banking, Consulting, Research, Training and Academics.

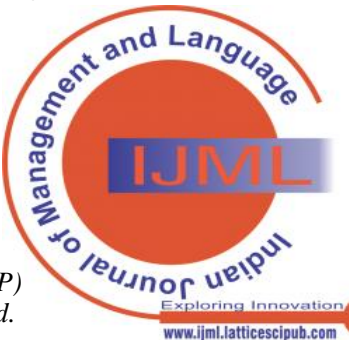


As an academic, he has held academic leadership positions for nearly ten years, and held Directorship / Deanship in three different Universities/ Institutions and has served as Chairman and member of Board of Studies and Academic Councils. His area of interest includes Risk, Banking Finance, Management, Strategy, Systems, Restructuring and is an avid inter-disciplinary researcher having published more than 60 publications in both National \& International Journals (incl. Gold Standard Publications like Australian Business Deans' Council rated (ABDC) and Scopus Indexed Publications)

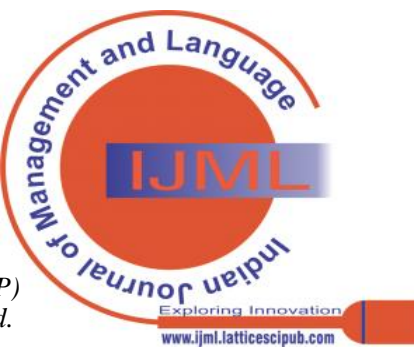

